\title{
Infection Prevention and Control Preparedness Level and Associated Determinants in 56 Acute Healthcare Facilities in Ghana
}

This article was published in the following Dove Press journal: Infection and Drug Resistance

\author{
Timothy Bonney Oppong $\mathbb{D}^{\prime}$ \\ Cecilia Amponsem-Boateng (D) \\ Emmanuel Kumi Duodu \\ Kyere ${ }^{\prime}{ }^{\prime}$ \\ Ying Wang \\ Zohreh Gheisari (iD) \\ Eunice Ekua Oppong ${ }^{2}$ \\ Godfrey Opolot $\mathbb{D}^{\prime}$ \\ Guangcai Duan' \\ Haiyan Yang' \\ 'Department of Epidemiology and \\ Biostatistics, College of Public Health, \\ Zhengzhou University, Zhengzhou, \\ Henan 45000I, People's Republic of \\ China; ${ }^{2}$ Medical Department, Entrance \\ University Hospital, Accra 00233, Ghana
}

Background: Infection prevention and control (IPC) is a globally relevant aspect of all health systems impacting the health and safety of both patients and healthcare workers. However, best practices remain a challenge in healthcare delivery especially in resource limited situations. The primary objective of this study was to assess the infection prevention and control (IPC) preparedness levels of acute healthcare facilities in Ghana and to determine the factors associated with the overall IPC preparedness levels in acute healthcare facilities. Methods: A cross-sectional study adapting the IPC assessment framework (IPCAF) developed by the World Health Organization (WHO) was conducted. Five of the core components of the WHO IPCAF were used to assess the IPC level of 56 acute healthcare facilities in Ghana.

Results: Of the 56 facilities surveyed, only 19 had an IPC program with clearly defined objectives. Overall, 8 (14.3\%) facilities scored an IPC preparedness level of "Advance", 18 (32.1\%) facilities received an "Intermediate" IPC preparedness score, 23 (41.1\%) facilities received an IPC preparedness level of "basic" and 7 (12.5\%) facilities scored an IPC preparedness level of "inadequate". IPC materials like detergents, running water and PPEs were not significantly supplied. Government owned facilities performed better in terms of IPC preparedness as compared to privately owned facilities. A PLUM-ordinal regression analysis revealed that an IPC program with clearly defined objectives ( $\mathrm{OR}=76 ; 95 \% \mathrm{CI} ; 7.23,808.19)$, dedicated IPC budget $(\mathrm{OR}=13 ; 95 \% \mathrm{CI} ; 3.8-44.3)$ and regular mandatory training $(\mathrm{OR}=50.9 ; 95 \% \mathrm{CI}$; 6.1-425) were associated with increased IPC preparedness.

Conclusion: Generally, the IPC preparedness levels in a majority of the facilities were low and required significant improvements in several areas. Facilities must make periodic reviews and adjust their objectives based on facility priorities.

Keywords: infection prevention and control, infection prevention preparedness, assessing infection prevention and control programs, infection prevention and control policy

\section{Introduction}

Infection prevention and control (IPC) is a globally relevant aspect of all health systems and impacts the health and safety of both people seeking health services and those who offer them. ${ }^{1}$ Consequently, it remains a universal healthcare challenge that most healthcare systems globally can relate to. ${ }^{2}$ It spans from the difficult task of preventing and controlling hospital acquired infections (HCAIs) to the surveillance of old and emerging infectious diseases, as well as dealing with the aftermath of disasters. $^{3-5}$
Correspondence: Haiyan Yang Department of Epidemiology and Biostatistics, College of Public Health Zhengzhou University, Henan 45000I,

People's Republic of China

Tel +86 I3592602629

Email yhy@zzu.edu.cn 
It is difficult to ascertain the global burden of HCAIs and results from different studies differ. Reports indicate that 5 to $10 \%$ of patients admitted to acute healthcare facilities acquire a HCAI and about 1.7 million patients acquire HCAIs while receiving medical care, resulting in more than 98,000 deaths annually. ${ }^{6,7}$ An estimated 2.6 million new cases of HCAIs occur in Europe annually while studies in both Europe and the USA indicate that the incidence density of HCAIs ranged from 13.0 to 20.3 episodes per thousand patient-days. ${ }^{8-10}$ Though data on HCAIs are scanty in low income countries, they are thought to be high for obvious reasons. For example, patients seeking medical care for other illnesses can acquire respiratory infections while waiting to be attended to due to overcrowding in health facilities. ${ }^{11,12}$

Well-planned and carefully implemented IPC programs reduce morbidity, prevent mortality and save money; yet proven interventions have not been widely adopted in resource constraint settings and standards of IPC vary widely. ${ }^{13}$ The WHO's guidelines for IPC preparedness at both national and facility levels provides 8 core components for an IPC program that can either be adapted or adopted to suit all facilities in different environmental and economic settings while maintaining the core components and scientific rigor. ${ }^{14}$ Also, the Ghana Ministry of Health updated its IPC policy and guidelines for national, regional and facility level in 2015 and is meant to direct all IPC work in healthcare facilities in the country. ${ }^{15}$ Recently, global public health emergencies such as the respiratory syndrome coronavirus in the Middle East and the Ebola virus disease outbreaks in West Africa, revealed gaps in IPC procedures applied by the countries concerned. ${ }^{1}$ Intrahospital infection and transmission of COVID-19 has already been reported as very high in many instances. ${ }^{16,17}$

Ghana had recorded 5,408 COVID-19 cases with 514 recoveries and 24 deaths as of May 13, 2020 with additional cases expected to be recorded each day. ${ }^{18}$ All healthcare facilities, including privately operated ones, are on high alert to respond to cases and even though current cases are being managed in designated facilities, patients are referred from all types of facilities to these designated testing and treatment facilities. It is therefore important to assess the IPC preparedness of healthcare facilities in order to identify vulnerable areas that need improvement. However, no such study has been done in Ghana. Therefore, this study was conducted to assess the IPC preparedness levels and its primary determinants in healthcare facilities in Ghana.

\section{Materials and Methods}

This study was a cross-sectional study with the use of a questionnaire as a quantitative tool. We adapted the IPC assessment framework (IPCAF) at facility level developed by the WHO to assess the IPC preparedness in acute care facilities in Ghana. ${ }^{19}$ The IPCAF consists of eight broad core components that can be adapted or adopted depending on the environmental or economic setting of the facility. In this study, facilities were assessed based on the following 5 core components: IPC program; IPC guidelines; IPC education and training; workload, staffing and bed occupancy; and built environment, materials and equipment for IPC at the facility level. The questionnaire was pretested in 5 facilities that were not included in this study.

Using the scoring procedure in the WHO IPCAF, the IPC preparedness was determined as either Advance, Intermediate, Basic or Inadequate. An "advance IPC preparedness level" indicates that "the IPC core components assessed are fully implemented according to the WHO recommendations and appropriate to the needs of the facility". An "intermediate IPC preparedness level" indicates that

most aspects of the IPC core components are appropriately implemented; as such, the facility should continue to improve the scope and quality of implementation and focus on the development of long-term plans to sustain and further promote the existing IPC program activities.

A "Basic IPC preparedness level" indicates that "some aspects of the IPC core components are in place, but not sufficiently implemented and that further improvement is required". Finally, an "inadequate IPC preparedness level" indicates that the "IPC core components implementation is deficient and therefore significant improvement is required".

We used paper balloting as a simple random sampling procedure to select 5 out of 16 regions in Ghana. Using a convenience sampling process, 90 healthcare facilities in the 5 randomly selected regions were invited to participate in the study taking easy accessibility and proximity to researchers into consideration due to limited resources. Permission was obtained from facilities, after which the Google form link to the assessment questionnaire was emailed to selected facilities. Where requested, a printed version of the assessment tool was hand delivered to the facility. Where an IPC related worker was not available, any acute care worker was eligible to answer it truthfully 
to reflect the actual situation in their facility. Since the tool assesses the facility and not the individual staff, respondents were allowed to ask or discuss with other colleagues where they were not sure of an answer. This was also done to ensure confidence that the data provided was reliable and accurate. All participants gave informed consent before answering the questionnaire. Ethical approval for this study was granted by the Life Science Ethics Review Committee of Zhengzhou University and Ashanti South Ghana Conference Health Ministry with clearance number ASSG/HM/11-2019/07.

\section{Statistical Analysis}

Responses were extracted from Google forms into Microsoft Excel. Where hard copies were submitted, researchers entered responses into Google forms verbatim, after which the data was cleaned, and imported into SPSS for analysis. Descriptive statistics were presented as frequencies and percentages. Chi-square analysis was performed to identify relationship between certain factors and IPC preparedness level. Finally, PLUM-ordinal regression was used to assess predictive factors for IPC preparedness levels in facilities. All statistical analysis was done in IBM SPSS, version 26.

\section{Results}

Out of the 90 facilities invited, a total of 56 acute healthcare facilities accepted to participate; making a response rate of $62.2 \%$. The 56 facilities were then surveyed with at least one healthcare professional answering the survey questions in each facility. In terms of facility ownership and management, 29 (51.8\%) were government facilities while the remaining $27(48.2 \%)$ were private facilities. Majority $(n=50 ; 89.35 \%)$ were general hospitals, 3 $(5.4 \%)$ were referral facilities, and $3(5.4 \%)$ were polyclinics. The following healthcare professionals answered the survey questions: 34 (60.7\%) nurses, 10 (17.9\%) doctors, $5(8.9 \%)$ physician assistants, 3 (5.4\%) ward assistants, $3(5.4 \%)$ nurse assistants and 1 (1.8\%) midwife. Other characteristics of surveyed facilities are presented in Table 1 .

\section{IPC Program}

A total of 19 (33.9\%) facilities were identified to have an IPC program with clearly defined objectives. In 28 $(50.0 \%)$ facilities, respondents indicated that there exists an IPC policy but without clearly defined objectives and they did not know much about it. However, there was no
Table I Characteristics of the 56 Included Healthcare Facilities Stratified by Region

\begin{tabular}{|c|c|c|c|c|}
\hline \multirow[t]{2}{*}{ Region } & \multirow{2}{*}{$\begin{array}{l}\text { No. of } \\
\text { Included } \\
\text { Hospitals }\end{array}$} & \multicolumn{2}{|c|}{ Management Type } & \multirow{2}{*}{$\begin{array}{l}\text { Average } \\
\text { Bed } \\
\text { Capacity }\end{array}$} \\
\hline & & Government & Private & \\
\hline $\begin{array}{l}\text { Greater } \\
\text { Accra }\end{array}$ & 15 & 9 & 6 & 66 \\
\hline Ashanti & 29 & 13 & 16 & 78 \\
\hline Western & 5 & 3 & 2 & 55 \\
\hline Eastern & 5 & 3 & 2 & 55 \\
\hline Bono & 2 & I & I & 50 \\
\hline
\end{tabular}

IPC program in $9(16 \%)$ facilities. About 28 (50\%) facilities had IPC teams comprising of IPC personnel supporting IPC programs in their facilities; 20 facilities had only IPC focal persons while 8 facilities had no IPC personnel in their facilities. In 21 (37.5\%) facilities, senior facility leadership took part in IPC related activities. While this was uncertain in 26 (46.4\%) facilities, it was certain senior facility leadership were not involved in IPC activities in the case of $9(16.1 \%)$ facilities. While 21 (37.5\%) of the facilities had a dedicated budget for IPC related activities, there was no indication of a dedicated budget in 35 $(62.5 \%)$ facilities. Microbiological laboratory support was available in $22(39.2 \%)$ facilities and delivering results reliably (timely and of sufficient quality). In 25 (44.5\%) facilities, microbiological laboratory was available but results were not delivered reliably. However, 9 facilities did not have any microbiological laboratories on site. Availability of IPC guidelines in facilities are represented in Table 2.

\section{Infection Prevention and Control (IPC) Education and Training}

In $20(35.7 \%)$ facilities, healthcare workers received periodic trainings related to new or updated IPC guidelines. This was however unidentified in the remaining 36 (64.3\%) facilities. Also, 25 (44.6\%) facilities indicated that they have had personnel with IPC expertise lead IPC training. This was however uncertain in the remaining facilities. Only $20(35.7 \%)$ facilities indicated that administrative and management staff join IPC trainings. It was however uncertain in the remaining 36 facilities. While 16 (28.6\%) facilities indicated regular (at least once annually) evaluation of IPC trainings received, evaluation was not regular in $32(57.1 \%)$ facilities with $8(14.3 \%)$ facilities indicating no reviews at all. Majority $(46 ; 82.1 \%)$ of the 
Table 2 A Presentation of the Availability of IPC Guidelines in the 56 Surveyed Facilities

\begin{tabular}{|l|l|l|l|l|}
\hline \multirow{2}{*}{ Guidelines } & \multicolumn{2}{l|}{ Yes } & \multicolumn{2}{l|}{ No } \\
\cline { 2 - 5 } & $\mathbf{n}$ & $\%$ & $\mathbf{n}$ & $\%$ \\
\hline Standard precautions & 39 & $69.6 \%$ & 17 & $30.4 \%$ \\
Injection safety & 42 & $75 \%$ & 14 & $25 \%$ \\
Transmission-based precautions & 42 & $75 \%$ & 14 & $25 \%$ \\
Prevention of surgical site infections & 38 & $67.9 \%$ & 18 & $32.1 \%$ \\
Hand hygiene & 50 & $89.3 \%$ & 6 & $10.7 \%$ \\
Outbreak management and & 37 & $66.1 \%$ & 19 & $33.9 \%$ \\
preparedness & & & & \\
Prevention of vascular catheter- & 24 & $42.9 \%$ & 32 & $57.1 \%$ \\
associated bloodstream infections? & & & & \\
Prevention of hospital acquired & 31 & $55.4 \%$ & 25 & $44.6 \%$ \\
pneumonia & & & & \\
Transmission of multidrug-resistant & 30 & $53.6 \%$ & 26 & $46.4 \%$ \\
pathogens & & & & \\
Catheter-associated urinary tract & 33 & $58.9 \%$ & 23 & $41.1 \%$ \\
infections & & & & \\
Disinfection and sterilization & 41 & $73.1 \%$ & 15 & $26.8 \%$ \\
Healthcare worker protection and & 42 & $75 \%$ & 14 & $25 \%$ \\
safety & & & & \\
Waste management & 42 & $75 \%$ & 14 & $25 \%$ \\
Antibiotic stewardship & 22 & $39.3 \%$ & 34 & $60.7 \%$ \\
\hline
\end{tabular}

facilities indicated no IPC training for patients and their families. A representation of frequency of IPC trainings and education in facilities is represented in Table 3.

\section{Workload, Staffing and Bed Occupancy}

Appropriate staffing levels were not regularly assessed in most $(29 ; 51.8 \%)$ of the facilities surveyed. Assessment of the right patient-staff ratio revealed the following: 18
(32.1\%) facilities had the right patient-staff ratio for staff in all units; 13 (23.2\%) facilities had the right patient-staff ratio in more than $50 \%$ of units in their facilities; 15 (26.8\%) facilities had the right patient-staff ratio in all units whereas $10(17.1 \%)$ facilities had the wrong patientstaff ratio in more than $50 \%$ of all the units in their facilities. Majority of the facilities had no system in place to act on even when staffing levels are deemed too low. A review of ward designs and bed occupancy in facilities is represented in Table 4.

\section{Built Environment, Materials and Equipment for IPC at the Facility Level}

Only 24 facilities had water services available every day and of sufficient quantity. Also, 24 facilities had safe drinking water station accessible for staff, patients and families at all times. Furthermore, only 20 facilities had quality water, soap and single use towels in all wards and at all points of care for hand hygiene practice. Again, only 24 facilities had toilet facilities of sufficient number and all functioning. However, a majority (46) of the facilities had a functioning ventilation at all points of care. On the other hand, a majority (40) of the facilities had materials such as detergents, mops and buckets available, however they were not enough or properly maintained. Again, a majority (37) of the facilities had no isolation rooms and of the 19 that had, only 17 had single rooms available. Furthermore, only 19 facilities had PPEs available and of sufficient quantity. Assessment of the availability of built environment, materials and equipment for IPC in facilities are represented in Table 5.

Table 3 A Representation of Employee Education and Training on IPC in 56 Healthcare Facilities

\begin{tabular}{|c|c|c|c|c|}
\hline \multirow[t]{2}{*}{ Questions } & \multicolumn{4}{|l|}{ Answers } \\
\hline & $\begin{array}{l}\text { New Employee } \\
\text { Orientation and Regular } \\
\text { Mandatory IPC Training } \\
\text { for All Health Care } \\
\text { Workers }\end{array}$ & $\begin{array}{l}\text { New Employee Orientation, at } \\
\text { Least Annual IPC Training, but } \\
\text { Attendance not Compulsory/for } \\
\text { Selected Workers }\end{array}$ & $\begin{array}{l}\text { New Employee } \\
\text { Orientation } \\
\text { Only for Health } \\
\text { Care Workers }\end{array}$ & $\begin{array}{l}\text { Neverl } \\
\text { Rarely }\end{array}$ \\
\hline $\begin{array}{l}\text { How frequently do health care } \\
\text { workers receive training regarding } \\
\text { IPC in your facility? }\end{array}$ & $n=17$ & $n=16$ & $n=16$ & $n=7$ \\
\hline $\begin{array}{l}\text { How frequently do cleaners and } \\
\text { other personnel directly involved in } \\
\text { patient care receive training } \\
\text { regarding IPC in your facility? }\end{array}$ & $n=16$ & $n=16$ & $n=16$ & $n=8$ \\
\hline
\end{tabular}


Table 4 A Representation of Review of Ward Design and Bed Occupancy in 56 Facilities

\begin{tabular}{|c|c|c|c|}
\hline Question & Answers & $\begin{array}{l}\text { Number } \\
\text { of } \\
\text { Facilities }\end{array}$ & $\%$ \\
\hline \multirow{3}{*}{$\begin{array}{l}\text { Is the design of wards in your facility } \\
\text { in accordance with international standards } \\
\text { regarding bed capacity? }\end{array}$} & Yes, in all departments & 14 & $25 \%$ \\
\hline & Only in certain departments & 23 & $41.1 \%$ \\
\hline & No & 19 & $33.9 \%$ \\
\hline \multirow{2}{*}{$\begin{array}{l}\text { Is bed occupancy in your facility kept to } \\
\text { one patient per bed? }\end{array}$} & Yes, in all departments & 32 & $57.1 \%$ \\
\hline & Only in certain departments & 24 & $42.9 \%$ \\
\hline \multirow{3}{*}{$\begin{array}{l}\text { Are patients in your facility placed in beds standing in the corridor outside } \\
\text { of the room (including beds in the emergency department) }\end{array}$} & Yes, more frequently than twice a week & 17 & $30.4 \%$ \\
\hline & Yes, less frequently than twice a week & 23 & $41.1 \%$ \\
\hline & No, not at all & 16 & $28.6 \%$ \\
\hline \multirow{3}{*}{$\begin{array}{l}\text { Is adequate spacing of at least I meter } \\
\text { between patient beds ensured in your } \\
\text { facility? }\end{array}$} & Yes, for all departments & 24 & $42.9 \%$ \\
\hline & Yes, but only in certain departments & 28 & $50 \%$ \\
\hline & No, spaces are smaller & 4 & $7.1 \%$ \\
\hline \multirow[t]{3}{*}{$\begin{array}{l}\text { Is a system in place in your facility to assess and respond when adequate } \\
\text { bed capacity is exceeded? }\end{array}$} & $\begin{array}{l}\text { Yes, this is the responsibility of the hospital } \\
\text { administration/management }\end{array}$ & 20 & $35.7 \%$ \\
\hline & $\begin{array}{l}\text { Yes, this is the responsibility of the head of } \\
\text { department }\end{array}$ & 24 & $42.9 \%$ \\
\hline & No & 12 & $21.4 \%$ \\
\hline
\end{tabular}

\section{Healthcare Facility IPC Preparedness Level and Determinants}

Overall, 8 (14.3\%) facilities received an IPC Preparedness Level of "Advance" and all 8 were facilities that had an IPC policy with clearly defined objectives. Next, 18 (32.1\%) facilities received an IPC Preparedness Level of "intermediate". Out of this, the majority (10) were facilities that had an IPC policy with clearly defined objectives; also, the majority (12) were government facilities. Twenty-three (41.1\%) facilities received an IPC Preparedness Level of "basic" with the majority (13) being private facilities. Lastly, 7 (12.5\%) facilities received an IPC Preparedness Level of "inadequate", of which 5 were private facilities. In general government facilities performed better in terms of IPC preparedness level. Chi-square analysis revealed a positive relationship between type of facility management (Government/Private) and IPC preparedness level, however statistically not significant at 0.05 significant level. An independent categorization was made for facilities with the availability of IPC policy with clearly defined objectives, dedicated budget for IPC activities and IPC training to determine if they had any significant bearing on the overall IPC preparedness level. A statistically significant positive relationship was seen between availability of IPC policy with clearly defined objectives $\left(X^{2}=24.3 ; \mathrm{p}=0.004\right)$, dedicated budget for IPC activities $\left(X^{2}=20.3 ; \mathrm{p}=<0.001\right)$, frequency of IPC education and training $\left(X^{2}=43.3 ; \mathrm{p}=<0.001\right)$ and IPC preparedness level. A PLUM-ordinal regression analysis revealed the following: firstly, the odds of a facility that has an IPC policy with clearly defined objectives to have an advance IPC preparedness was $76(95 \% \mathrm{CI} ; 7.23,808.19)$ times that of a facility with no IPC policy or an IPC policy without clearly defined objectives, with a statistically significant effect (Wald $\left.X^{2}=12.99 ; \mathrm{p}=<0.001\right)$. Again, the odds of a facility that has a dedicated budget for IPC activities to have an advance IPC preparedness was 13 (95\% CI; 3.8-44.3) times that of a facility without a dedicated budget for IPC related activities, with a statistically significant effect (Wald $X^{2}=16.5$; $\mathrm{p}=<0.001)$. Regular training on IPC could alsobe a predictor for IPC level. The odds of facilities with at least an annual training on IPC having an advance IPC preparedness was $50.9(95 \% \mathrm{CI} ; 6.1-425)$ times more than facilities without regular IPC training. 
Table 5 Assessment of the Availability of Built Environment, Materials and Equipment for IPC in 56 Facilities

\begin{tabular}{|c|c|c|c|}
\hline Question & Answers & $\begin{array}{l}\text { No. of } \\
\text { Facilities }\end{array}$ & $\%$ \\
\hline \multirow{3}{*}{$\begin{array}{l}\text { Are water services available at all times and of sufficient quantity for } \\
\text { all uses (hand washing, drinking, personal hygiene, medical activities, } \\
\text { sterilization, decontamination, cleaning and laundry)? }\end{array}$} & Yes, every day and of sufficient quantity & 24 & $42.9 \%$ \\
\hline & $\begin{array}{l}\text { Available on average } \geq 5 \text { days per week or every day } \\
\text { but not of sufficient quantity or flow }\end{array}$ & 20 & $35.7 \%$ \\
\hline & $\begin{array}{l}\text { Available on average less than } 5 \text { days per week/or } \\
\text { mostly on and off }\end{array}$ & 12 & $21.4 \%$ \\
\hline \multirow{3}{*}{$\begin{array}{l}\text { Is a reliable safe drinking water station present and accessible for } \\
\text { staff, } \\
\text { patients and families at all times and in all locations/wards }\end{array}$} & Yes, accessible at all times and for all wards/groups & 24 & $42.9 \%$ \\
\hline & $\begin{array}{l}\text { Sometimes, or only in some places or not available } \\
\text { for all users }\end{array}$ & 25 & $44.6 \%$ \\
\hline & No, not available & 7 & $12.5 \%$ \\
\hline \multirow[t]{4}{*}{$\begin{array}{l}\text { Do you have quality running water, soap and single-use towels in all } \\
\text { wards and at all points of care for hand hygiene practices? }\end{array}$} & $\begin{array}{l}\text { Yes, present to all with reliable supplies available all } \\
\text { the time }\end{array}$ & 19 & $33.9 \%$ \\
\hline & $\begin{array}{l}\text { Yes, stations present to all, but supplies are not } \\
\text { available all the time }\end{array}$ & 17 & $30.4 \%$ \\
\hline & Yes, present to only staff & 18 & $32.1 \%$ \\
\hline & No, not present & 2 & $3.6 \%$ \\
\hline \multirow{3}{*}{$\begin{array}{l}\text { Do you have alcohol-based hand-rub solution available at all point of } \\
\text { care for hand hygiene practices? }\end{array}$} & Yes, present to only staff & 24 & $42.9 \%$ \\
\hline & $\begin{array}{l}\text { Yes, stations present to all, but supplies are not } \\
\text { available all the time }\end{array}$ & 28 & $50 \%$ \\
\hline & No, not present & 4 & $7.1 \%$ \\
\hline \multirow{3}{*}{$\begin{array}{l}\text { Are there enough toilet facilities or improved latrines in this facility? } \\
\geq 4 \text { toilets for outpatient settings } \geq \text { I per } 20 \text { users for inpatient } \\
\text { settings? }\end{array}$} & Sufficient number present and all functioning & 23 & $41.1 \%$ \\
\hline & Sufficient number present but not all functioning & 29 & $51.8 \%$ \\
\hline & Less than required number available and functioning & 4 & $7.1 \%$ \\
\hline \multirow{3}{*}{$\begin{array}{l}\text { Is there sufficient power supply in your facility day and night for all } \\
\text { purposes such as pumping and boiling water, sterilization and } \\
\text { decontamination, lighting in toilet, etc }\end{array}$} & Yes, always and in all areas & 23 & $41.1 \%$ \\
\hline & Yes, but sometimes/periodic offs & 30 & $53.6 \%$ \\
\hline & No & 3 & $5.4 \%$ \\
\hline \multirow{2}{*}{$\begin{array}{l}\text { Is functioning environmental ventilation available in patient care } \\
\text { areas? }\end{array}$} & Yes & 46 & $82.1 \%$ \\
\hline & No & 10 & $17.9 \%$ \\
\hline \multirow[t]{3}{*}{$\begin{array}{l}\text { Do you have accessible records for the cleaning of floors and walls, } \\
\text { signed by cleaners each day? }\end{array}$} & $\begin{array}{l}\text { Yes, records completed and signed daily exist that } \\
\text { you can check }\end{array}$ & 21 & $37.5 \%$ \\
\hline & $\begin{array}{l}\text { Record exists, but is not completed and signed daily } \\
\text { or is outdated }\end{array}$ & 29 & $51.8 \%$ \\
\hline & There are no such records & 6 & $10.7 \%$ \\
\hline \multirow{2}{*}{$\begin{array}{l}\text { Are appropriate and well-maintained materials (like detergent, mops, } \\
\text { buckets, etc) for cleaning available? }\end{array}$} & Sufficiently available and well maintained & 15 & $26.8 \%$ \\
\hline & Available but not enough/maintained & 41 & $73.2 \%$ \\
\hline
\end{tabular}

(Continued) 
Table 5 (Continued).

\begin{tabular}{|c|c|c|c|}
\hline Question & Answers & $\begin{array}{l}\text { No. of } \\
\text { Facilities }\end{array}$ & $\%$ \\
\hline \multirow[t]{2}{*}{ Do you have isolation rooms in this facility? } & Yes, isolation rooms are available & 19 & $33.9 \%$ \\
\hline & We make room when needed & 37 & $66.1 \%$ \\
\hline \multirow{3}{*}{$\begin{array}{l}\text { Do you have single patient rooms or rooms for cohorting patients } \\
\text { with similar pathogens if the number of isolation rooms is insufficient } \\
\text { (for example, TB, measles, cholera, Ebola, SARS)? }\end{array}$} & Yes, single rooms are available & 17 & $30.4 \%$ \\
\hline & $\begin{array}{l}\text { No single rooms but rooms suitable for patient } \\
\text { cohorting available. }\end{array}$ & 34 & $60.7 \%$ \\
\hline & No & 5 & $8.9 \%$ \\
\hline \multirow{3}{*}{$\begin{array}{l}\text { Is PPE available at all times and in sufficient quantity for all uses for all } \\
\text { health care workers? }\end{array}$} & Yes, continuously available in sufficient quantities & 19 & $33.9 \%$ \\
\hline & $\begin{array}{l}\text { Yes, but not continuously available in sufficient } \\
\text { quantities }\end{array}$ & 33 & $58.9 \%$ \\
\hline & No & 4 & $7.1 \%$ \\
\hline \multirow[t]{3}{*}{ Do you reliably have sterile and disinfected equipment ready for use? } & Yes, available every day and of sufficient quantity & 23 & $40.1 \%$ \\
\hline & $\begin{array}{l}\text { Yes, available on average } \geq \text { five days per week or } \\
\text { every day, but not of sufficient quantity }\end{array}$ & 28 & $50 \%$ \\
\hline & No. Available on the average $<5$ days per week & 5 & $8.9 \%$ \\
\hline \multirow{2}{*}{$\begin{array}{l}\text { Are disposable items available when necessary? (For example, } \\
\text { injection safety devices, examination gloves, etc.) }\end{array}$} & Yes, continuously available & 25 & $44.6 \%$ \\
\hline & Yes, but only sometimes available & 31 & $55.4 \%$ \\
\hline
\end{tabular}

\section{Discussion}

We assessed the IPC preparedness level of 56 acute care facilities in Ghana using 5 of the core components of the WHO IPCAF. ${ }^{19}$ Overall, only 8 facilities met all 5 criteria used for assessment in this study and thus were deemed to have an advance IPC preparedness. All of the core components come together to make an IPC program effective and sustainable over a long period of time. Though IPC preparedness is a critical aspect of both patient's recovery and healthcare workers protection, there seems to be an underperformance in most facilities as far as this study is concerned.

The underperformance in IPC preparedness in most countries, especially in sub-Saharan Africa has always been as a result of speculation because of the obvious limited resources. No study was found on the extensive review of IPC preparedness level in healthcare facilities, especially guided by the WHO IPCAF. IPC audit is essential in ensuring that services in facilities are measured against standards. ${ }^{20}$ This current study presents the actual evidence of IPC preparedness level in Ghana and can be used as a baseline study for sub-Saharan Africa and gives a clearer view of IPC performance in the region. This study has highlighted that an IPC program with clearly defined objectives, dedicated budget for IPC activities and regular training on IPC are central to attaining a good IPC preparedness level.

The WHO highly recommends that the organization of IPC programs must have

clearly defined objectives based on local epidemiology and priorities according to risk assessment and functions that align with and contribute to the prevention of HCAI and the spread of AMR in health care. ${ }^{1,21}$

Our findings support this recommendation as we discovered a positive relationship between an IPC program with clearly defined objectives and the advance IPC level. The odds of a facility with clearly defined IPC objectives having a better IPC overall outlook was much higher than facilities without. Other studies agree that a clear communication about IPC guidelines and policy is very vital. ${ }^{22}$

In this study, $50 \%$ of surveyed facilities had IPC programs with objectives that were not clearly defined and understood by healthcare workers. This was consequently reflected in the overall IPC preparedness level of most of the facilities. More $41 \%$ of the facilities scored a "basic 
IPC preparedness level". According to the WHO IPCAF, ${ }^{19}$ a basic IPC level indicates that for the facilities concerned, some aspects of the IPC core components are in place, but not sufficiently implemented and this can explain why in the majority of the facilities, healthcare workers did not know much about the IPC program. To resolve this gap, it is imperative that IPC education is intensified in the facilities. Actually, there was no indication that workers received at least annual trainings related to new or updated IPC guidelines in $64.3 \%$ of the facilities. Survey audits often lack details such as training materials and mode of delivery. Therefore, as reported by Wang et al, in China, even in facilities where education and training takes place, it is difficult to assess this training and whether it is

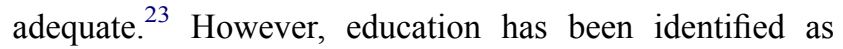
one of the key strategies for IPC implementation. ${ }^{24}$ In fact, regular IPC training was a predictor for advance IPC preparedness in this study.

Senior facility leadership participated in IPC related activities in only $37.5 \%$ of facilities surveyed. This contravenes the Ghana National IPC policy which specifically states that heads of facilities must be responsible for IPC activities. ${ }^{15}$ Gilbert and Kerridge ${ }^{25}$ asserts that absent leadership is often also associated with poor IPC practice. This is an indication that when facility leadership is absent with regards to IPC activities, it negatively affects compliance. Senior facility leadership support cannot be limited to attending IPC related meetings but must also be demonstrated in the availability of a dedicated budget for IPC activities. We identified only 21 facilities with a dedicated budget for IPC activities. This corresponds with studies in China where only a third of secondary/tertiary care facilities had a dedicated budget for IPC activities. ${ }^{23}$ Unsurprisingly, the Ghana National IPC policy only encourages facilities to have a dedicated IPC budget, not making it mandatory. ${ }^{15}$ However, we identified that a dedicated budget for IPC activities was directly related to an increased IPC preparedness. The unavailability of a dedicated budget was reflected in several IPC components. For example, only 19 facilities indicated the availability of sufficient quantities of PPE. Again, in 40 facilities, items like detergents, mops and buckets were not sufficiently available and water and toilet facilities were not sufficiently available and well maintained (Table 5). All of these significant aspects of IPC can be related to facility leadership involvement and support for IPC related activities.

These profound lapses can significantly affect IPC preparedness, practices and compliance. For example, hand hygiene remains the single most significant action that can prevent HCAIs, and indeed, Oppong et $\mathrm{al}^{26}$ asserts that hand washing must become a habit, performed intrinsically whenever needed and must not be the result of a decision. However, this is impossible to achieve when basic IPC supplies like sufficient flow of water, single use towels and soap are not adequately available.

\section{Limitations}

The major limitation of this study is that researchers used convenience sampling method in this study due to very limited resources. Also, the sample size of the hospitals used might not be a true representation of the whole population of hospitals in Ghana as most regions were not covered due to resource constraints.

\section{Conclusion}

This study presents the current performance of IPC preparedness level and serves as a true reference resource for government and policy makers. This study also revealed that IPC policy with clearly defined objectives, dedicated IPC budget and IPC training are central to better IPC preparedness level. Generally, the IPC preparedness levels in a majority of the facilities required significant improvements. We recommend that acute care facilities make a periodic review of their IPC priorities in order to incorporate strategic objectives relevant to their local epidemiology in order to contribute to the level of prevention of HCAIs and ultimately protect both patients and healthcare workers. The national IPC technical committee is responsible for monitoring and evaluating the implementation of IPC activities at all levels. They must intensify their monitoring mandate to ensure adequate compliance.

\section{Data Sharing Statement}

Data can be obtained from the corresponding author with a reasonable written request.

\section{Ethics Approval}

Ethical approval for this study was granted by the Life Science Ethics Review Committee of Zhengzhou University and Ashanti South Ghana Conference Health Ministry with clearance number ASSG/HM/11-2019/07.

\section{Acknowledgments}

We thank all the acute care hospitals who took part in this study; more importantly the respondents who took time to answer the questionnaire. 


\section{Funding}

This study was supported by the National Natural Science Foundation of China (No. 81973105).

\section{Disclosure}

All authors declare no conflict of interests.

\section{References}

1. Storr J, Twyman A, Zingg W, et al. Core components for effective infection prevention and control programmes: new WHO evidence-based recommendations. Antimicrob Resist Infect Control. 2017;6(1):6. doi:10.1186/s13756-016-0149-9

2. WHO HCAI. The burden of health care-associated infection worldwide. WHO; 2013. Available from: https://www.who.int/gpsc/ country_work/burden_hcai/en/. Accessed May 13, 2019.

3. Izumikawa $\mathrm{K}$. Infection control after and during natural disaster. Acute Med Surg. 2019;6(1):5-11. doi:10.1002/ams2.367

4. Gayer M, Legros D, Formenty P, Connolly MA. Conflict and emerging infectious diseases. Emerg Infect Dis. 2007;13(11):1625-1631. doi:10.3201/eid1311.061093

5. WHO. WHO report on global surveillance of epidemic-prone infectious diseases - introduction. WHO; 2015. Available from: https:// www.who.int/csr/resources/publications/introduction/en/index $5 . h t m l$. Accessed July 22, 2019.

6. Burke JP. Infection control - a problem for patient safety. $N$ Engl J Med. 2003;348(7):651-656. doi:10.1056/NEJMhpr020557

7. Haque M, Sartelli M, McKimm J, Abu Bakar M. Health care-associated infections - an overview. Infect Drug Resist. 2018;11:2321-2333. doi:10.2147/IDR.S177247

8. Behnke M, Aghdassi SJ, Hansen S, Diaz LAP, Gastmeier P, Piening B. The prevalence of nosocomial infection and antibiotic use in German Hospitals. Dtsch Arztebl Int. 2017;114(50):851-857. doi:10.3238/arztebl.2017.0851

9. Khan HA, Baig FK, Mehboob R. Nosocomial infections: epidemiology, prevention, control and surveillance. Asian Pac J Trop Biomed 2017;7(5):478-482. doi:10.1016/J.APJTB.2017.01.019

10. Ripabelli G, Salzo A, Mariano A, Sammarco ML, Tamburro M. Healthcare-associated infections point prevalence survey and antimicrobials use in acute care hospitals (PPS 2016-2017) and long-term care facilities (HALT-3): a comprehensive report of the first experience in Molise Region, Central Italy, and targeted intervention strategies. J Infect Public Health. 2019;12(4):509-515. doi:10.1016/j. jiph.2019.01.060

11. World Health Organization. Report on the burden of endemic health care-associated infection worldwide clean care is safer care. 2011. Available from: www.who.int. Accessed May 13, 2019.

12. Masavkar SP, Naikwadi AM, Masavkar SP. Knowledge, attitude and practice regarding nosocomial infections among general health practitioners and medical college students. Sch J Appl Med Sci. 2016;4:1852-1856
13. Godfrey C, Schouten JT. Infection control best practices in clinical research in resource-limited settings. J Acquir Immune Defic Syndr. 2014;65(Suppl 1):S15-8. doi:10.1097/QAI.0000000000000034

14. World Health Organization. Guidelines on core components of infection prevention and control programmes at the national and acute health care facility level. 2016. Available from: http://apps.who.int/ bookorders. Accessed August 16, 2019.

15. Ministry of Health. National policy and guidelines for infection prevention and control in health care settings. Available from: https://www.ghanahealthservice.org/downloads/National_Policy_ and_Guidelines_for_Infection_Prevention_and_Control_in_Health_ Care_Settings_2015.pdf. Accessed July 17, 2019.

16. Huang C, Wang Y, Li X, et al. Clinical features of patients infected with 2019 novel coronavirus in Wuhan, China. Lancet. 2020;395 (10223):497-506. doi:10.1016/S0140-6736(20)30183-5

17. China says more than 3,000 medical staff infected by COVID-19 CNA. Available from: https://www.channelnewsasia.com/news/asia/ covid19-china-says-medical-staff-infected-by-coronavirus-12466054. Accessed April 11, 2020.

18. COVID-19 updates | Ghana. Available from: https://ghanahealthser vice.org/covid19/. Accessed April 11, 2020.

19. WHO. Infection prevention and control assessment framework at the facility level introduction and user instructions. 2018. Available from: http://www.who.int/infection-prevention/publications/core-com-. Accessed August 16, 2019.

20. Gorrell M. Infection prevention and control self-audit: just a tick box exercise? $J$ Infect Prev. 2014;15(2):64-68. doi:10.1177/ 1757177413512388

21. Ripabelli G, Tamburro M, Guerrizio G, Fanelli I, Agnusdei CP, Sammarco ML. A single-arm study to evaluate skin tolerance, effectiveness and adherence to use of an alcohol-based hand rub solution among hospital nurses. $J$ Infect Prev. 2019;20(5):224-230. doi:10.1177/1757177419846295

22. Houghton C, Meskell P, Delaney H, et al. Barriers and facilitators to healthcare workers' adherence with infection prevention and control (IPC) guidelines for respiratory infectious diseases: a rapid qualitative evidence synthesis. Cochrane Database Syst Rev. 2020;4 (4):1-55. doi:10.1002/14651858.CD013582

23. Wang J, Liu F, Tan JBX, Harbarth S, Pittet D, Zingg W. Implementation of infection prevention and control in acute care hospitals in Mainland China - a systematic review. Antimicrob Resist Infect Control. 2019;8(1):1-16. doi:10.1186/s13756-019-0481-y

24. Barrera-Cancedda AE, Riman KA, Shinnick JE, Buttenheim AM. Implementation strategies for infection prevention and control promotion for nurses in Sub-Saharan Africa: a systematic review. Implement Sci. 2019;14(1). doi:10.1186/s13012-019-0958-3

25. Gilbert GL, Kerridge I. The politics and ethics of hospital infection prevention and control: a qualitative case study of senior clinicians, perceptions of professional and cultural factors that influence doctors ' attitudes and practices in a large Australian hospital. BMC Health Serv Res. 2019;19(1):212. doi:10.1186/s12913-019-4044-y

26. Oppong TB, Yang H, Amponsem-Boateng C, Duan G. Hand hygiene habits of ghanaian youths in Accra. Int $J$ Environ Res Public Health. 2019;16(11):1964. doi:10.3390/ijerph16111964

Infection and Drug Resistance

Dovepress

\section{Publish your work in this journal}

Infection and Drug Resistance is an international, peer-reviewed openaccess journal that focuses on the optimal treatment of infection (bacterial, fungal and viral) and the development and institution of preventive strategies to minimize the development and spread of resistance. The journal is specifically concerned with the epidemiology of

antibiotic resistance and the mechanisms of resistance development and diffusion in both hospitals and the community. The manuscript management system is completely online and includes a very quick and fair peerreview system, which is all easy to use. Visit http://www.dovepress.com/ testimonials.php to read real quotes from published authors. 